\title{
THE TERMINAL DISINTEGRATION OF STEENSBY GLETSCHER, NORTH GREENLAND
}

\author{
By Frank Ahnert \\ (Department of Geography, University of Maryland, College Park, Maryland, U.S.A.)
}

\begin{abstract}
Steensby Gletscher, located between Nyeboes Land and Warming Land, is one of the few Arctic ice streams with a floating tongue. It differs from other floating glaciers of the Arctic in that it discharges into a fjord with open water in the summer, in the presence of crevasses on its floating tongue, and in the way its terminus disintegrates areally into sublobes rather than shedding "Arctic" type icebergs by simple calving.

The glacier's terminal disintegration is ascribed to a slight northward bend of the fjord stretch which contains the floating tongue. The tongue, moving into the bend along a straight path, runs marginally aground near the shore at the outside of the bend, while the still-floating central part of the tongue continues to move forward. This leads to rotational movement of parts of the tongue which split off from the main ice mass along major crevasses to form sublobes separated from each other by wide gaps, and connected with the main ice mass only at their roots.
\end{abstract}

Résumé. Le Steensby Gletscher, situé entre Nyeboes Land et Warming Land, est l'un des quelques fleuves de glace de l'Arctique ayant une langue flottante. Il diffère des autres glaciers flottants de l'Arctique dans le fait qu'il se décharge dans un fjord occupé par l'eau libre en été, dans la présence de crevasses sur sa langue flottante et dans la façon dont la surface de sa terminaison se décompose en sublobes plutôt qu'en icebergs du type de perte arctique par simple vêlage.

La décomposition de la terminaison du glacier est attribuée à une légère courbure vers le nord de l'extension du fjord qui contient la langue flottante. La langue, se déplaçant dans la courbure de façon rectiligne, s'écoule marginalement sur le sol, près du rivage à l'extérieur de la courbure, tandis que la partie centrale encore flottante continue à avancer au-delà. Ceci conduit à un mouvement rotationnel des parties de la langue qui se séparent de la principale masse de glace le long des crevasses importantes pour former des sublobes séparés les uns des autres par de larges vides et reliés avec la masse de glace principale seulement
à leurs racines.

Zusammenfassung. Der Steensby Gletscher, zwischen Nyeboes- und Warming Land gelegen, ist einer der wenigen arktischen Eisströme mit schwimmender Zunge. Er unterscheidet sich von anderen schwimmenden Gletschern der Arktis dadurch, dass er in einen Fjord ausströmt, der im Sommer offenes Wasser aufweist, ferner dadurch, dass er Spalten auf der ausströmenden Zunge hat und sein Ende sich infolgedessen der Fläche nach in sekundäre Lappen auf löst. Er sendet also nicht durch einfaches Kalben Eisberge vom
"arktischen" Typ aus.

Die beschriebene Auflösung des Gletscherendes wird einer leichten nördlichen Biegung des FjordVerlaufs zugeschrieben, die die schwimmende Zunge enthält. Die Zunge, die sich in die Biegung des Fjords geradlinig hineinbewegt, stösst mit ihrem Ende in Ufernähe auf Grund und zwar auf der Aussenseite der Biegung, während der noch schwimmende zentrale Zungenteil sich weiterbewegt. Dies führt zu einer Drehbewegung von Teilen der Zunge, die von der Haupteismasse entlang grösseren Spalten absplittern und sekundäre Lappen bilden. Diese sind voneinander durch weite Lücken getrennt und nur an ihren Wurzeln mit der Haupteismasse verbunden.

In contrast to the Antarctic, where many glaciers descending to the sea have large floating extensions, the Arctic contains very few floating ice tongues (Charlesworth, 1957, p. 1 73-74). Koch (1928, p. 370-7I) asserted for north Greenland that the present dry climate, and particularly the absence of low summer temperature, is responsible for this difference. He ascribed the existence of two floating tongues observed by him in north Greenland, Petermanns Gletscher and Ryder Gletscher (Fig. I), to local conditions, namely, low gradients and therefore no crevasses at the boundary between the floating and the fixed part, and possibly the existence of permanent sea ice which presses against the glacier front. Both Petermanns Gletscher and Ryder Gletscher are described as being very smooth, and the floating tongue of Petermanns Gletscher as not crevassed; both have floating tongues several tens of kilometers long (Koch, I928, p. 289-300). In his account of glaciers in north Greenland, Koch also included a brief observational note on Steensby Gletscher (so named by him), of which he only saw the outlet and upper part; a sharp bend in the glacier concealed its lower part from his view. Aerial photographs taken in 1947 reveal that the tongue of Steensby Gletscher is also floating. Although this floating section is much shorter than those of Petermanns Gletscher 
and Ryder Gletscher, Steensby Gletscher commands particular interest; it possesses - contrary to the conditions outlined by Koch-large crevasses, and because it disintegrates areally rather than producing neatly separated icebergs by calving along its forward edge, the phrase terminal disintegration seems more appropriate as a term to describe the break-up of the Steensby Gletscher ice tongue than the customary "calving".

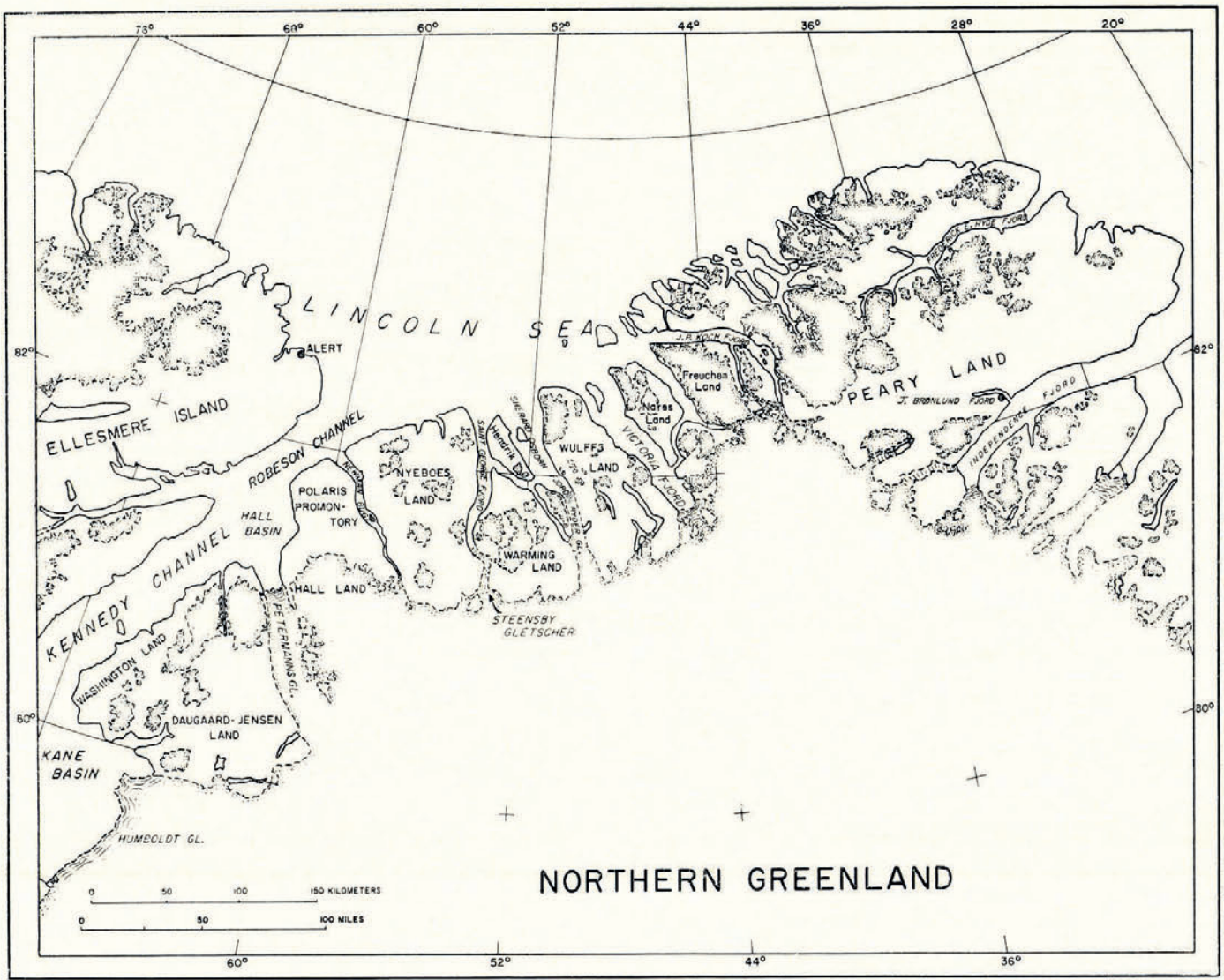

Fig. I. Map of northern Greenland showing the relative position of Steensby Gletscher

Vertical and oblique aerial photographs, from which Figure 3 was assembled, were used as an observational basis for this investigation. A detailed map (Fig. 4) of the lower part of Steensby Gletscher was made by direct tracing from the vertical photographs, and with the help of a Canadian grid for that part which only appears on obliques. Use of this grid was possible because of the extremely low gradient of the glacier.

\section{Location And Dimensions}

The ice stream of Steensby Gletscher leaves the inland ice at approximately lat. $8 \mathrm{I}^{\circ} \mathrm{I} 2^{\prime} \mathrm{N}$., long. $52^{\circ} 35^{\prime} \mathrm{W}$. and flows in a northerly direction, separating Nyeboes Land in the west from Warming Land in the east. Its lower third bends sharply off to the west-north-west, and the disintegrating terminus, floating in St. George Fjord, again points northward (Fig. 2). The overall length of the glacier, from the outlet to the most forward point of contiguous glacier ice, is (in May I 947) about $48 \mathrm{~km}$. Near the outlet the glacier is approximately I I $\mathrm{km}$. wide 
but the lower two-thirds have a rather uniform width of 4 to $5 \mathrm{~km}$. Part of the wider ice mass near the outlet spills over to the west, as a small secondary tongue whose tip nearly touches that of another small ice lobe flowing around the west side of Porsild Nunatak.

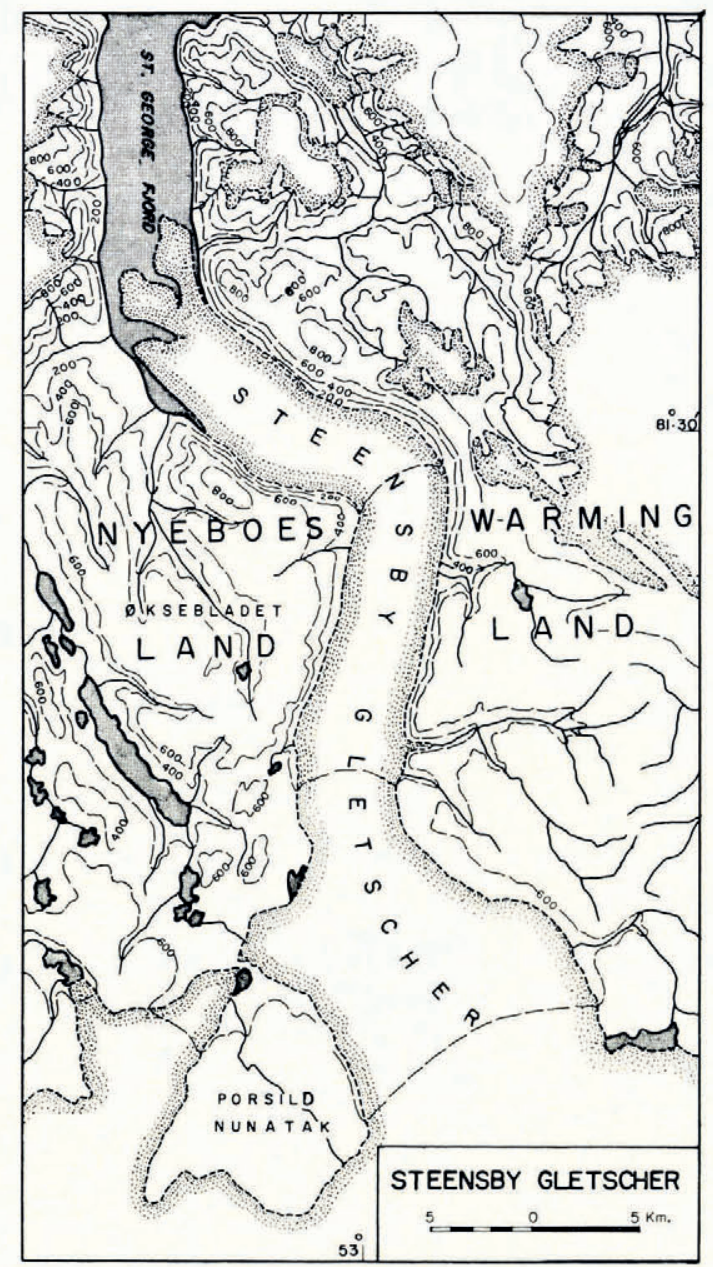

Fig. 2. Detailed map of Steensby Gletscher

One property Steensby Gletscher has in common with the other two floating ice tongues of north Greenland is its low gradient; from the outlet to the west-north-west bend it remains rather uniformly at $1 \cdot 4$ per cent. Because available maps show no contours on the lowest part, no determination of gradient could be made there; but, since the lowermost $8 \mathrm{~km}$. of the tongue are floating, it is obviously even less.

No direct measurements of the thickness of the glacier are available. However, following the assumption that floating glacier ice reaches about four to five times as far below the water level as it projects above it (Drygalski, I897, p. 404), the height of ice cliffs in the floating part was determined on the original air photographs by means of an Austin photo-interpretometer in squares $\mathrm{C}_{2}, \mathrm{D} 4$ and D5 of Figure 4. The cliffs thus measured range in height from $\mathrm{I}_{5}$ to $18 \mathrm{~m}$., indicating for the floating tongue a thickness of only $75^{-108} \mathrm{~m}$. Near the outlet the 
Fig. 3 .

Steensby Gletscher seen from the north (II May 1947). Warming Land lies on the left and Nyeboes Land on the right with Porsild Nunatak in the right background (compare with Figures 2 and 4). The lower part of this composite photograph consists of vertical photographs, the upper part is an oblique view. (U.S. Air Force pholographs)

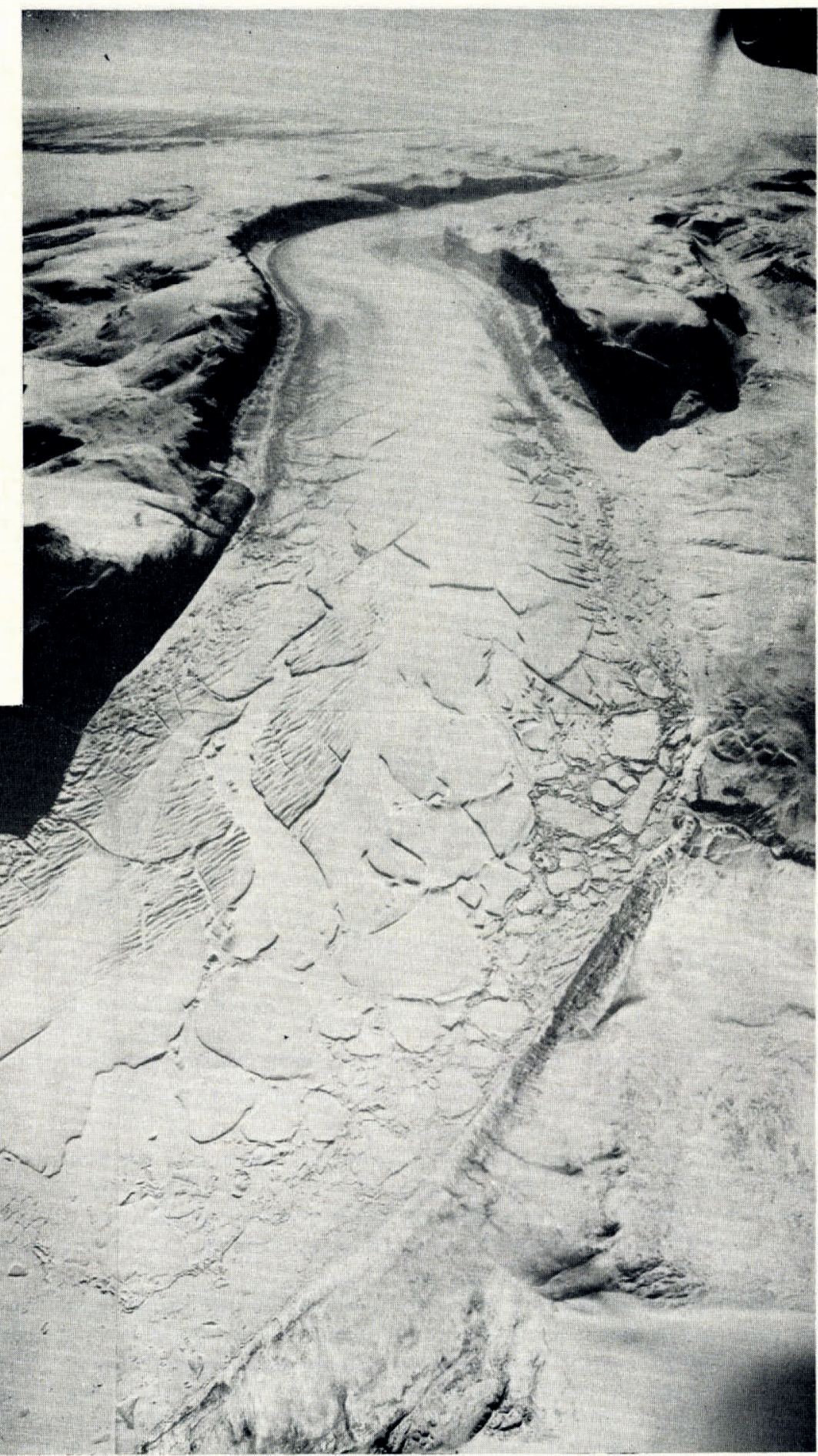




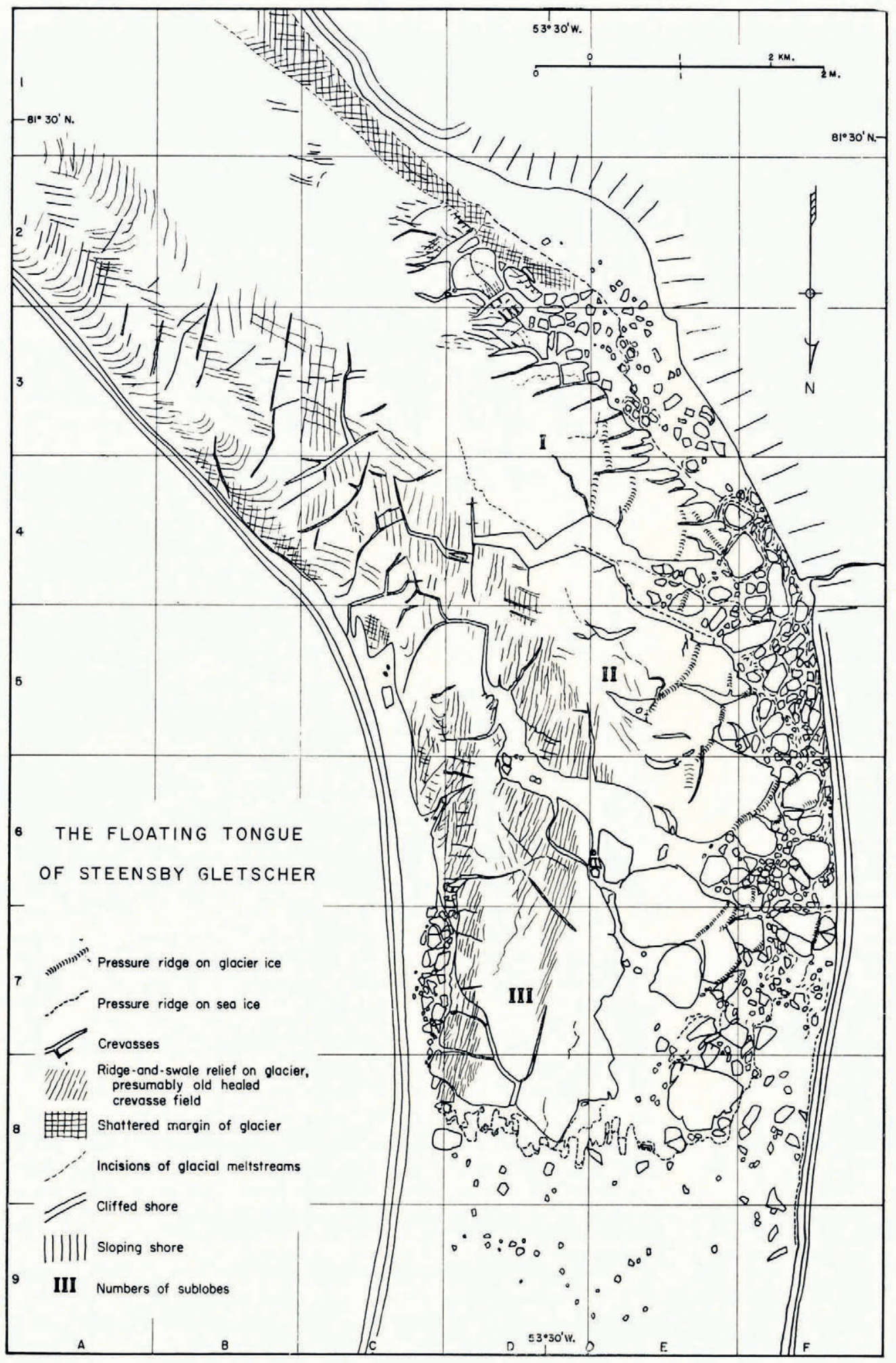

Fig. 4. Map of the floating tongue of Steensby Gletscher (cf. Fig. 3) 
thickness is most likely not too much greater. Although there is an increasing loss by ablation from the outlet down-glacier, the outlet is much wider than the ice stream farther down; also, in the gently sloping outlet area the surface of the glacier does not rise much above the adjacent land surface. Thus, compared to its width, Steensby Gletscher appears to be quite shallow.

\section{Terminal Disintegration}

The floating tongue of the glacier has been very conspicuously split up into three sublobes, numbered I, II and III on Figure 4. Sublobe I is still firmly connected with the main mass of the glacier, while sublobes II and III appear to be nearly detached by large crevasses. Two long gaps, both narrowing headwards, separate the sublobes. The angular outline of the gap between sublobes I and II (especially in square D4 of Figure 4), and its headward ending in a crevasse, demonstrate clearly that it has been formed by the widening of a long major crevasse. The gap between sublobes II and III displays more rounded outlines, but then there are in its vicinity also curving crevasses, especially on sublobe III (C5, D5 and D6 of Figure 4), indicating that this gap, too, developed through the widening of a crevasse system. In both gaps the outlines of opposite sides match like pieces of a jigsaw puzzle, if one disregards the icebergs lying in the wide mouths of the gaps. Thus the gaps obviously were not formed by the removal of glacier ice through melting or calving, but by the moving apart of the sublobes from each other in a direction roughly transverse to the axis of the glacier. The amount of such transverse movement increased "down-stream", i.e. towards the terminus, as the increase in the width of the gaps shows.

In conjunction with this transverse movement the occurrence of ridges on the glacier ice is of particular interest (Fig. 4). They are present only on sublobes I and II, along the west side of the glacier, and appear as a series of crests, each having a width in the order of magnitude of $50 \mathrm{~m}$., and spaced several hundred meters apart. On sublobe I (Fig. 3) their height increases noticeably from the central part of the glacier westward and "down-stream". The outline of the ridges is, as a rule, gently arcuate, with the convex side facing forward and to the western margin.

The causes for these "waves" in the glacier ice could be either subglacial obstacles or longitudinally differential movement within the ice itself. Of these alternatives, subglacial obstacles (rock barriers or old end moraines) have to be ruled out because (a) the nearhorizontal bedding of the sedimentary rocks in this area is not likely to permit the formation of subglacial rock barriers of this kind and outline; (b) old terminal moraines, consisting of loose material, would probably be easily removed by the glacier; (c) the ridges are entirely confined to the sublobes and are absent on the main ice mass farther up-stream, although there is no reason why subglacial barriers should not also occur up-stream, if there are any at all-so that the origin of the ridges seems directly connected with the break-up of the glacier tongue into sublobes; and (d) the spacing, outline and the regular increase in height and sharpness of the ridges from the center to the margin marks them as a rhythmic phenomenon originating within the ice itself rather than brought about by the overriding of subglacial obstacles. Therefore, they are to be interpreted as glacial pressure ridges.

The cross-profiles of the pressure ridges on sublobe I become increasingly asymmetric from the center to the margin of the glacier (Fig. 3). The innermost wave (along the eastern edge of $\mathrm{E}_{4}$ on Figure 4) is a very gentle, broad rise with no appreciable asymmetry; the next one to the west has a more gentle eastern slope, but a western (landward) slope steep enough to cause a darker tone on the photograph (Fig. 3). Near the base of that landward slope the ice surface is somewhat rough, apparently beginning to break. The third and most pronounced ridge on sublobe I, finally, has a strongly accentuated, locally very steep landward slope with an irregular surface, and is quite narrow. Such asymmetric cross-profiles have been described by Klebelsberg ( $194^{8-49}$, p. I I6) as being characteristic for transverse waves (Querwellungen) 
which develop on glaciers independently from the textural properties of the icc. In the case of Steensby Gletscher the cause of their existence lies in the bend of the glacier bed near the terminus from a north-westerly to a northerly direction, and in the fact that in the southern part of this bend the main mass of the glacier begins to float. Movement of a non-floating glacier is controlled by the pressure of ice from up-glacier and by the gradient and configuration of the glacier bed. In a bend of such a glacier all of its parts are guided into the curve, differential movements notwithstanding, by the shape of the subglacial surface with which the glacier is in contact across its entire width. Movement of a floating glacier, however, is independent from the bottom configuration and in both its direction and speed is solely determined by the push of the ice from behind. Upon becoming buoyant, then, the floating ice tongue will tend to move forward on a straight path whose orientation is identical with that of the non-floating pushing glacier mass immediately behind it. Thus, the floating tongue of Steensby Gletscher retains the tendency to move north-westward-in the direction in which the non-floating part flows-while the glacial valley (or rather the head of the fjord) turns northward, resulting in an oblique impingement of the floating tongue upon the western bank. Owing to the shoreward rise of the fjord bottom the western edge of the floating tongue runs aground, while the push of the ice from up-glacier persists. The ice thus becomes subject to compression and the pressure ridges form. Away from the margin the compression leads mainly to plastic deformation involving a broad part of the ice, and appearing at the surface as a broad, smooth and gently sloping ridge, as exemplified by the innermost ridge on sublobe I. Towards the margin, however, with the firmly resistant fjord bottom immediately ahead, and the sub-surface of the ice jammed upon and against it, plastic deformation is less possible, and much of it is supplanted by shear movement. The most accentuated ridge on sublobe I has been formed in this manner, with ice having been forced over the ice stranded ahead, along a shear plane striking parallel to the ridge itself and dipping toward the central part of the glacier. The irregularity of the steep landward slope of this ridge is ascribed to mechanical stresses produced by the shear along the forward edge of the overriding ice. The triangular section of ice immediately landward from the northern (and highest) part of this ridge has been visibly tilted eastward by the added weight of the ice overriding it from the east, as the westward widening shadow of its northern edge shows on the photograph (Fig. 3). The ridge between this one and the gentle innermost one seems to represent an intermediate form between the two extremes, with its generally smooth surface indicating predominant plastic deformation, and the roughness at its landward base hinting the start of shear movements.

On sublobe II even the innermost pressure ridge (E5 on Figure 4) is strongly developed. The ridges near the end of sublobe II (F6 on Figure 4) have been caused by the pressure of the contiguous glacier ice against tabular icebergs which are apparently stranded; they differ from the ridges within the contiguous glacier in that either both the edge of the glacier and that of the iceberg have been upturned along the contact, or the thinner fjord ice between them has been compressed and forced up into "ice welts" higher than the glacier surface. Such welts of pack ice also surround the closely crowded icebergs between sublobe II and the land. Upturned edges also occasionally are observable where one iceberg presses against another. Along some of the contacts between the glacier and tabular icebergs it seems that glacier and icebergs have been reunited by compression, a circumstance which corresponds to observations made by Drygalski ( 1897, p. I31) on the Jakobshavns Isbræ.

The nature and distribution of the pressure ridges on the glacier ice, together with the wide gaps between the sublobes, provide the clues for the understanding of the terminal disintegration of Steensby Gletscher. As the floating tongue moved into the northward bend at the head of St. George Fjord its western margin, represented mainly by the forward part of sublobe I, became stranded on the fjord bottom near the shore while the more central parts of the glacier, still afloat, were pushed on in a north-westerly direction. With its tip aground, 
yet its inner parts being pushed farther north-westward, sublobe I rotated counter-clockwise and split off from the main ice mass along crevasses which now appear as the gap between sublobes I and II. Evidence for the rotational character of this movement is the increase in the width of the gap from the center to the margin of the glacier. The rotation of sublobe I and the general north-westerly flow of the glacier combined within that sublobe into a resultant westward motion which is demonstrated by the (approximately) north-south trend of its pressure ridges. Sublobe II, lying approximately in the extension of the axial part of the glacier, continued to move north-westward-thereby widening the gap between itself and sublobe I- until its forward edge, too, ran aground near the northward-curving shore, and then also began to rotate in a counter-clockwise direction; this rotation opened the gap between sublobes II and III. However, it was less intensive than the rotation of sublobe I. The ice movement within sublobe II remains directed more to the north-west as shown by the orientation of its pressure ridges; but clear evidence that some rotation of sublobe II took place is provided by a pressure ridge of fjord ice, running along the side of sublobe II in the gap between sublobes I and II. The third, easternmost sublobe of the ice tongue is the only one that has negotiated the northward bend without having run into obstacles. It appears to float entirely in sufficiently deep water. Sublobe III is not only well split off from sublobe II through the latter's rotation; owing to the numerous large crevasses near its root, it also has a rather weak connection with the glacier up-stream, so that it could swing to the north. Possibly the clockwise turn of sublobe III was aided by some bottom friction along its eastern margin up-glacier; however, this cannot be ascertained from the photograph. The distribution of icebergs, and the generally smooth surface of the sea ice in the gaps and ahead of the glacier prove that St. George Fjord has open water during the summer. This observation invalidates the suggestion by Koch (1928, p. 37 I)-which Charlesworth quite categorically states as a necessary condition-that floating glacier tongues in the Arctic can only exist where the fjords they enter are "densely packed with permanent sea-ice" (Charlesworth, 1957, p. I 74). It is very likely, however, that the open water of St. George Fjord in summer has greatly facilitated the far-reaching terminal disintegration of Steensby Gletscher, in contrast to Ryder Gletscher and Petermanns Gletscher whose ice fronts, according to Koch, end in fjords occupied by pack ice of greater permanency.

Judging by the smoothness of the ice within the gaps, the separation of the sublobes must have occurred mainly during a time when the fjord was unfrozen with only some further rotation after freeze-up, which caused the pressure ridge in the sea ice along the south-west side of sublobe II. No direct information is available on the velocity of Steensby Gletscher; nevertheless, the high ridges of pack ice squeezed up between the icebergs along its western side make the pressure induced by the ice motion, and hence the velocity of this motion, appear considerable. Assuming the glacier to have an average velocity within the lower part of the range listed by Charlesworth (1957, p. I04) for outlet glaciers in Greenland, namely, I 5-24 m./day, one gets an annual advance of between 5,475 m. and 8,760 m.; the length of the disintegrating floating tongue of Steensby Gletscher (about $8 \mathrm{~km}$.) lies between these values, and therefore very probably came into its floating position during the preceding year. As the highest velocities are commonly reached in spring and summer (Drygalski, I897, p. I3 I ; Charlesworth, 1957, p. 103), the disintegration of the tongue as depicted on the photograph (Fig. 3) and the map (Fig. 4) most likely is the result of a single open-water season. In conjunction with this deductive reasoning it is of interest to note the presence of pressure ridges, similar to those on sublobes I and II, on the large tabular iceberg complex in square E7 of Figure 4. It seems that at least some of these ridges have been caused by plastic deformation which is characteristic of the contiguous glacier mass but not of icebergs, and that they therefore have formed when the iceberg was still part of the glacier, so that it represents a large fragment of a sublobe from an earlier year. Indeed, many of the icebergs along the western side of the glacier may have been trapped here from previous years, since very few 
bergs are found in the fjord ahead of the glacier. Those that did drift seaward into the fjord rise, as a rule, to lesser heights above the fjord than do the icebergs close to the glacier and the cliffed edges of the glacier itself. Possibly shoals near the terminus of the glacier prevent the bergs of greater height and therefore deeper draught from floating away.

Besides the large tabular icebergs which have calved off the floating sublobes where crevasses are widely spaced, Steensby Gletscher also produces numerous smaller icebergs of the "Arctic" type. They come mainly from the zones shattered by dense crevassing along the eastern margin and, headward from sublobe I, also along the western margin. Those on the eastern margin ( $\mathrm{c} 7$ on Figure 4) move, though detached, along with the glacier until they are released at the end. Many of those along the western margin appear trapped behind the ice jam of tabular bergs. Only a few very small icebergs have drifted into the little cove at D2-E2 of Figure 4 and the water here is obviously very shallow.

One other peculiar feature worth attention is the pressure ridge on the fjord ice ahead of the glacier (D8 and E8 of Figure 4). Induced by the pushing force of the advancing glacier against the fjord ice, it nevertheless touches the glacier only at a few places and has formed some distance away. Even more remarkable is its course, bending back and forth, with short transverse stretches in between. A possible explanation is that the glacier pushes sections of the fjord ice ahead of it along shear surfaces marked by the longitudinal limbs of the pressure ridge. Different slabs of fjord ice are pushed forward for different distances. The fjord ice immediately glacier-ward of the ridge is comparatively rough; the pressure of the glacier may have caused areal buckling here in addition to the formation of the ridge itself. The roughness seems greater behind those transverse stretches of the ridge which are closer to the glacier, suggesting that their lesser forward motion was compensated by greater buckling behind them.

MS. received 20 fuly 1962 and in revised form 29 October 1962

\section{REFERENCES}

Charlesworth, J. K. 1957. The Quaternary era, with special reference to its glaciation. London, Edward Arnold (Publishers) Ltd. 2 vols.

Drygalski, E. von. 1897. Grönland-Expedition der Gesellschaft für Erdkunde zu Berlin, 1891-1893. Bd. I. Grönlands Eis und sein Vorland. Berlin, W. H. Kuhl.

Klebelsberg, R. von. I948-49. Handbuch der Gletscherkunde und Glazialgeologie. Wien, Springer-Verlag. 2 vols.

Koch, L. 1928. Contributions to the glaciology of north Greenland. Meddelelser om Gronland, Bd. 65, p. $18 \mathrm{I}-464$. 